\title{
Determinant genes that effect the central nervous system and their antenatal identification
}

\author{
ChristyVijay ${ }^{1}$, Preetha Tilak ${ }^{2 *}$
}

\begin{abstract}
${ }^{1}$ Department of Obstetrics and Gynecology, ${ }^{2}$ Department of Human Genetics, St. John's Medical College and Hospital, Bangalore, Karnataka, India
\end{abstract}

Received: 03 September 2020

Accepted: 08 October 2020

*Correspondence:

Dr. Preetha Tilak,

E-mail: preetha444@yahoo.co.in

Copyright: (C) the author(s), publisher and licensee Medip Academy. This is an open-access article distributed under the terms of the Creative Commons Attribution Non-Commercial License, which permits unrestricted non-commercial use, distribution, and reproduction in any medium, provided the original work is properly cited.

\section{ABSTRACT}

Background: The central nervous system is an intricate networking of electric signals that intertwines the functioning of all senses of speech, thoughts etc. A genetic mutation in this complex structure is known to cause many neurological diseases.

Methods: Records of the genetic analysis reports of patients were studied. Patients with CNS genetic syndromes or tubulinopathies in fetus of the present pregnancy or previous pregnancy who presented themselves only for genetic counseling with the genetic analysis report done at an outside diagnostic center were selected.

Results: Ten patients presented with history congenital abnormalities of the structure of the central nervous system in pregnancy. Non-invasive investigations in the first child led to the need for genetic analysis of the present foetus. EEG showing independent S2 foci and left central parietal and right temporal region with bilateral synchronous discharge was noticed. MRI findings such as chronic infarct with encephalomalacia were seen.

Conclusions: Our study identified genes responsible for CNS abnormalities in structure and function and the Exom sequence in which they occurred. We were able to observe various types of clinical presentations of the syndromes on MRI/USG.

Keywords: Antenatal, CNS, Consanguineous, Genes, Heterozygous, Tubulinopathies

\section{INTRODUCTION}

The central nervous system is an intricate networking of electric signals that intertwines the functioning of all senses of speech, thoughts etc. ${ }^{1}$ The vertebrate central nervous system (CNS) has elaborated on the structure of neural gene of proteates to produce a complex structure. ${ }^{2}$ A genetic mutation in this complex structure is known to cause many neurological diseases. ${ }^{1}$

Impaired cortical development is known to cause epilepsy in human beings and this development of the cortex involves three overlapping processes of neuronal and glial proliferation, neuronal migration and cortical organization. ${ }^{3}$ Malformations are known to have a genetic origin and some may be linked to prenatal insult. ${ }^{3}$ Tubulinopathies associated with overlapping range of brain malformations caused by mutation of one of seven genes encoding different isotypes, while Lissencephaly ranges from complete absence of sulci (agyria) to a thickened cortex. ${ }^{4}$

These neurological diseases are usually due to dynamic mutations, as seen in Huntington's disease. ${ }^{1}$ These genes which are responsible for RNA and protein expression are polygenic and polymorphism can influence the expression of these genes and target proteins. ${ }^{5}$ Human studies have shown gene variants in the form of insertions, deletions, inversions etc. ${ }^{5}$ Neurological diseases like Nijmigen breakage syndrome and ataxia 
telengectasia are closely related to single gene disorders that have several signal transduction pathways. ${ }^{6}$ Frameshift and nonsense mutations play a role in neurological diseases especially in biochemically proved adrenomyeloneuropathy. ${ }^{7}$ Recent advances have shown adhesion molecules like Po, L1 and merosin which are responsible for the myelination of Corpus Callosum and Corticospinal tract, when mutated cause abnormalities in the nervous system development, leading to the belief that syndromes related to the CNS are dependent on multifunctional molecules. ${ }^{8}$

As very few studies have looked into antenatal modalities in investigating genes responsible for CNS syndromes ,our study was conducted to observe possible genetic mutations responsible for various CNS associated syndromes in humans identified in the antenatal period.

Aims and objectives of the study was to determine the genetic mutations responsible for CNS mutation and tubulinopathies and to determine the mode of investigation and associated features seen on non invasive antenatal modalities.

\section{METHODS}

This was a retrospective descriptive record study. Patients with CNS genetic syndromes or tubulinopathies who presented themselves only for genetic counseling at St. Johns Medical College and Hospital ,with a genetic analysis report done at an outside diagnostic center, where the diagnosis of any abnormal gene affecting the CNS, had been established, were included in the study. Records of the genetic analysis report and folders of patients were studied from $1^{\text {st }}$ January 2019 to $30^{\text {th }}$ June 2020.Ethical approval was obtained: IEC Study No.167/2020.

All records that identified any CNS genetic abnormality in the pregnancy and had features of tubulinopathies were selected. However, exclusion of other genetic abnormalities of peripheral nervous system and other systems were considered.

Patient records were coded to prevent the identification of any individual subject and only the research team handled the data. No treatment was provided for the patients and prenatal diagnostic tests were not performed at the center. Patients were given only genetic counseling. The physicians had no part in the decision making of the outcome of the pregnancy and absolute independence of the decision of the patient and family to decide on the continuation of the pregnancy was ensured.

\section{Analysis}

Data was analysed using the SPSS versions 16 after it was manually entered in Micro Soft Excel. Simple frequency and percentages was used for analysis.

\section{RESULTS}

Our study looked into the case reports and genetic analysis of ten patients with history of congenital abnormalities of the central nervous system. The samples collected were blood from the patient, cord blood, Chorionic villus sampling, and amniotic fluid. Four patients had history of consanguineous marriage. Gene mutation and disease associated with the same was evaluated. Of the 6 babies who required immediate resusucitation, one expired in immediate neonatal period due to birth asphyxia (intrapartum fetal distress at 32 weeks in woman with severe preeclampsia), one expired after 10 days due to metabolic complications and the rest four survived.

\section{Indications for genetic analysis in present pregnancy}

Most of the above pregnancies showed abnormalities in the structures of the central nervous system of the foetus. MRI of one such foetus showed total callosal agenesis with colpocephaly, with cerebral medial frontoparietal abnormal cortical indentations with irregular subjacent ventricular contour grey matter signal nodularity, with altered signs across white matter consistent with polymicrogyria with periventricular heterotopia. Another showed suspected micro-tubulinopathy or $\mathrm{X}$ linked hydrocephalus while others show micro lissencephaly and grey white differentiation. These features in antenatal non-invasive testing indicated the need for genetic analysis.

\section{Indications for gene analysis with past affected pregnancy}

Most mothers had history of prior pregnancy loss. One patient had history of two Medically Terminated Pregnancies, due to club foot retrognathia, polyhydramnios, kyphosis and other congenital anomalies. Positive genetic abnormalities in the first sibling or first cousin, such as autism spectrum disorder, poor eye contact, epilepsy, healing loss, neonatal seizures, microcephaly, bilateral epicanthal folds, bilateral forefoot adduction, bilateral low set ears, and mild Mental retardation were observed.

Non invasive investigations in the first child led to the need for genetic analysis of the present foetus. Findings like EEG showing independent S2 foci and left central parietal and right temporal region with bilateral synchronous discharge was noticed in one pregnancy. MRI findings such as chronic infarct with encephalomalacia, changes with gliosis in right temporoparietal lobe with hemosiderin staining along gyri, hypomyelinating leukodystrophy mesial temporal lobe and hippocampus bilateral, suspecting mesial temporal sclerosis. Ultrasound findings of lessincephaly and tubulinopathy were seen in some. 
History of a father suffering from rod and cone dystrophy, retinitispigmentosa, macular degeneration, post axial polydactyly and bilateral clinodactyly of the 5 th toe was observed in one of the records.

Table 1: Genes coding for tubulinopathy.

\begin{tabular}{|c|c|c|c|c|c|}
\hline Gene & Disease (inheritance) & Exon & Zygosity & Type & Consanguinity \\
\hline OFD1 & $\begin{array}{l}\text { Joubert syndrome } \\
\text { 10/Orofaciodigital } \\
\text { Syndrome I (XLR/XLD) }\end{array}$ & Ex 12 & Heterozygous & Pathogenic & 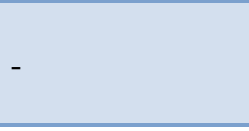 \\
\hline $\begin{array}{l}\text { C8orf37 } \\
\text { NM_177965.3 }\end{array}$ & \multirow{2}{*}{$\begin{array}{l}\text { Baret -Biedl syndrome }-21 \\
\text { (BBS21) }\end{array}$} & Ex 1 & Homozygous & $\begin{array}{l}\text { Likely } \\
\text { pathogenic }\end{array}$ & \multirow{2}{*}{$\begin{array}{l}\text { Consanguineous } \\
\text { marriage }\end{array}$} \\
\hline Cdhr1nm_033100.3 & & Ex 11 & Homozygous & $\begin{array}{l}\text { Uncertain } \\
\text { significance }\end{array}$ & \\
\hline NAA15 & $\begin{array}{l}\text { Mental Retardation autosomal } \\
\text { dominant } 50(\mathrm{AD})\end{array}$ & Ex 19 & Heterozygous & $\begin{array}{l}\text { Variant of } \\
\text { uncertain } \\
\text { significance }\end{array}$ & - \\
\hline \multirow[b]{2}{*}{ L1CAM } & \multirow{2}{*}{$\begin{array}{l}\text { Detected in index patient } \\
\text { (elder sibling) } \\
\text { Missense variation } \\
\text { ChrX: } 153132233 \mathrm{C}>\mathrm{T}\end{array}$} & \multirow[b]{2}{*}{ Ex 19} & Hemizygous/ & \multirow[b]{2}{*}{ Pathogenic } & \multirow[b]{2}{*}{-} \\
\hline & & & Homozygous & & \\
\hline COL11A1 & Fibrochondro-genesis 1 (AR) & Ex 8 & $\begin{array}{l}\text { Heterozygous } \\
\text { (Carrier) }\end{array}$ & $\begin{array}{l}\text { Likely } \\
\text { pathogenic }\end{array}$ & $\begin{array}{l}\text { Consanguineous } \\
\text { marriage }\end{array}$ \\
\hline CRPPA & $\begin{array}{l}\text { Muscular dystrophy } \\
\text { Dystroglycanopathy } \\
\text { (congenital with brain and eye } \\
\text { anomalies) } \\
\text { Type A, } 7 \text { (AR) }\end{array}$ & Ex 10 & Homozygous & $\begin{array}{l}\text { Variant of } \\
\text { uncertain } \\
\text { significance }\end{array}$ & 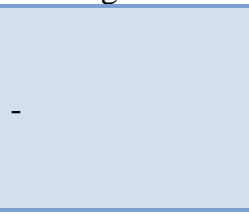 \\
\hline EIF2AK3 & $\begin{array}{l}\text { Wolcott-Rallison syndrome } \\
\text { (AR) }\end{array}$ & Ex 9 & Heterozygous & $\begin{array}{l}\text { Likely } \\
\text { pathogenic }\end{array}$ & - \\
\hline FOXRED1 & $\begin{array}{l}\text { Mitochondrial complex I } \\
\text { deficiency, } \\
\text { Nuclear type } 19 \text { (AR) }\end{array}$ & Ex 6 & $\begin{array}{l}\text { Heterozygous } \\
\text { (Carrier) }\end{array}$ & $\begin{array}{l}\text { Likely } \\
\text { pathogenic }\end{array}$ & \multirow{2}{*}{$\begin{array}{l}\text { Consanguineous } \\
\text { marriage }\end{array}$} \\
\hline PARS2 & $\begin{array}{l}\text { Epileptic encephalopathy, } \\
\text { early infantile ,75 (AR) }\end{array}$ & $\mathrm{EX} 2$ & Homozygous & $\begin{array}{l}\text { Variant of } \\
\text { uncertain } \\
\text { significance }\end{array}$ & \\
\hline ASPM & $\begin{array}{l}\text { Microcephaly 5,primary } \\
\text { autosomal receive (AR) }\end{array}$ & Ex 2 & Homozygous & Pathogenic & - \\
\hline $\begin{array}{l}\text { PYCR2 } \\
\text { NM_013328.3 }\end{array}$ & $\begin{array}{l}\text { Pyrroline-5-carboxylate } \\
\text { reductase is a mitochondrial } \\
\text { enzyme }\end{array}$ & Ex 4 & Homozygous & $\begin{array}{l}\text { Likely } \\
\text { Pathogenic }\end{array}$ & $\begin{array}{l}\text { Consanguineous } \\
\text { marriage }\end{array}$ \\
\hline
\end{tabular}

Table 2: Questionnaire.

What is already known

Genes are responsible for CNS associated genetic abnormalities

Outcomes of CNS genetic abnormalities

Type of genetic inheritance pattern in tubulinopathies.

\section{What this study adds and recommendation}

Location of genes that are responsible for CNS genetic abnormalities or Tubulinopathies

Clinical presentation of genetic mutations of the CNS antenatally and findings on USG.

Correlation of various tubulinopathies and type of inheritance

Syndromic presentation of various CNS defects and tubulinopathies.

\section{DISCUSSION}

Our study ventured into the various congenital developmental anomalies that involved the CNS and looked into the gene mutations associated with them. We identified 12 genes responsible for syndromes primarily affecting the CNS. Most of these syndromes were homozygous and pathogenic in nature.

Tubulinopathies manifest in a wide range of various abnormalities such as lissencephaly, agyria-pachygyria- 
band spectrum, dysgyria, heterotopia, commissural anomalies, anomalies of deep cerebellar nuclei, Hippocampal anomalies , corticospinal tract anomalies, hypoplasia of the brainstem and cerebellar hemispheres and vermis etc. ${ }^{3}$ These changes and characteristics were similarly observed in the reports of our study.

We identified syndromes which could present with mental autism, seizures, mental retardation, similar to other autosomal disorders like Tuberous sclerosis complex characterized by hamartomas and similar clinical presentation. This points to the possibility that most CNS associated genetic mutations may occur at a common or specified parent loci. ${ }^{9}$ We identified certain similarities between Joubert syndrome identified in our study and Tuberous sclerosis, where in both diseases were caused by mutated heterozygous genes. Our study identified OFD1 to be the pathogenic gene in fetus to cause Joubert syndrome, while Erik et al identified Tsc gene to cause Tuberous sclerosis in mice. Both diseases are known to cause similar clinical presentations like seizures etc, further substantiating the former theory. ${ }^{9}$

Bahi et al characterized tubulinopathies and lissencephalies by cerebellar hypoplasia, agenesis of the corpus callosum, and centrally predominant pachygyria, corpus callosum abnormalities, and hypoplasia or dysplasia of the brain stem and cerebellum. ${ }^{4}$ These clinical features were noticed in the MRI and USG reports of our subjects. The study went on to describe that these diseases included motor and intellectual disabilities, epilepsy, and ocular findings of varying severity and the inherited pattern to be an autosomal dominant manner and de novo heterozygous pathogenic variant. ${ }^{4}$ Similar characteristics and findings were noticed in our results. ${ }^{4}$ A study stated patients with cortical abnormalities like micropolygyria, have epilepsy to not be intractable, and full control may be obtained by medical treatment. ${ }^{10}$ Clinical features of our patients showed similarities with those described by Andermann et al. such as perisylvian polymicrogyria. The study went onto stress the importance of callosotomy with caution in patients with micropolygyria. ${ }^{10}$

Most pregnancies observed in our study showed abnormalities in the structure of the CNS of the foetus with positive MRI findings. A study by Christian $\mathrm{H}$ et al showed normal Karyotype of 14 out of 22 paediatric anaplastic astrocytomas and all anaplastic astrocytomas had DNA copy number. ${ }^{11}$

Another study in rat spinal cord showed clones of abundant unknown gene of myelin constituting protein and myelin associated oligodendritic basic protein. ${ }^{12}$ These studies could explain the gross changes in the CNS that take place and diagnosed on Magnetic resonance Imaging(MRI)/ Ultrasonogram (USG).

The possibility of the genes identified in our study to have tumerogenic potential cannot be ruled out. Ayesha et al stated that tumours have a high progressive rate based on genetic analysis, just like endometrial Carcinoma and P1K3C gene. ${ }^{13}$ Kanno et al studied 13 cases with primary sporadic hemangioblastoma for somatic mutation of VLH gene with analysis of DNA detected abnormal single strand conformational polymorphism, which was observed due to mutation in Exom 1 and 2.14 Our study identified Baret -Biedl syndrome 21 for Exom 1 and Microcephaly -5 and epileptic encephalopathy for Exom 2. The above syndromes substantiate the theory that single strand DNA mutation of an Exom causes a vast range of genetic disease spectrum of the CNS.

Antenatal infections can cause these genetic mutations of the CNS as seen in a Boston study where newborn mice were intracerebrally inoculated with type 3 reovirus causing necrotising encephalitis compared to those which developed hydrocephalus with type 1 virus and S1 gene segment was responsible for the neurovirulence. 15 These findings direct us to evaluate subclinical viral infections in the aetiology of tubulinopathies in humans.

Our study showed many gene mutations positive for CNS defects which had developmental motor impairment. One study by Heglind et al pointed the role of Foxs 1 in the investigation and processing of neuronal signals important for motor functioning. ${ }^{16}$ Imaging plays a crucial role in identifying abnormal lesions in the brain specially for diseases like Von Hippel Lindau. ${ }^{17}$

Our study showed antenatal non invasive imaging to be an important modality for identifying lesions on MRI like callosal agenesis, signal nodularities, polymicrogyria and other tubulinopathies. Similar findings of lessencephaly were seen in USG. Our study further substantiates the need for ANC imaging in identifying CNS abnormalities due to genetic abnormalities. ${ }^{17}$

\section{CONCLUSION}

Our study identified genes responsible for CNS abnormalities in structure and function and the Exom sequence in which they occurred. We were able to observe various types of clinical presentation of syndromes on MRI and USG. The need for antenatal surveillance and investigations like USG etc. can help patients face a better outcome of the subsequent pregnancies. Multidimensional approach, such as supportive care including physical therapy to manage spasticity, occupational therapy, and speech therapy to be counselled. Seizures to be treated with antiepileptic drugs and requirement of nonsurgical and surgical treatment to be explained to parents at the time of genetic counseling.

\section{Recommendations}

Need for vigilant antenatal screening and adequate and timely counselling of patients with a family history of 
tubulinopathies, in order to help in better outcomes of future pregnancies.

\section{ACKNOWLEDGMENTS}

Authors would like to thank the Department of Genetics and the Department of Obstetrics and Gynecology of St. John's Medical College and Hospital for the unconditional service rendered throughout the processing of the research study.

Funding: No funding sources Conflict of interest: None declared

Ethical approval: The study was approved by the Institutional Ethics Committee

\section{REFERENCES}

1. Achim CL, Everall IP. Effects of aging on HIVassociated brain disease. HIV and Aging. 2008;27:23.

2. Imai KS, Stolfi A, Levine M, Satou Y. Gene regulatory networks underlying the compartmentalization of the Ciona central nervous system. Development. 2009;136(2):285-93.

3. Gonçalves FG, Tomás de Andrade LF, Taranath A, Lakshmanan R, Goetti R, Feltrin FS, Mankad K, Teixeira SR, Hanagandi PB, Arrigoni F. Tubulinopathies. Topics in magnetic resonance imaging. 2018;27(6):395-408.

4. Buisson B, Cavallin M. Tubulinopathies overview. Gene Reviews. 2016;7:88-94.

5. Sierra H, Cordova M, Chen CSJ. Confocal imagingguided laser ablation of basal cell carcinomas: an ex vivo study. J Invest Dermatol. 2015;135(2):612-5.

6. Shiloh Y. Ataxia-telangiectasia and the Nijmegen breakage syndrome: related disorders but genes apart. Annual Rev Genetics. 1997;4:31.

7. Braun A, Ambach H, Kammerer S. Mutations in the gene for X-linked adrenoleukodystrophy in patients with different clinical phenotypes. Am J Hum Genet. 1995;56(4):854-861.

8. Kamiguchi H, Hlavin ML, Yamasaki M, Lemmon V. Adhesion molecules and inherited diseases of the human nervous system. Annual review of neuroscience. 1998;21(1):97-125.

9. Uhlmann EJ, Apicelli AJ, Baldwin RL, Burke SP, Bajenaru ML, Onda H, Kwiatkowski D, Gutmann
DH. Heterozygosity for the tuberous sclerosis complex (TSC) gene products results in increased astrocyte numbers and decreased p27-Kip1 expression in TSC $2+/-$ cells. Oncogene. 2002;21(25):4050-9.

10. Jansen A, Andermann E. Genetics of the polymicrogyria syndromes. J Med Genetics. 2005;42(5):369-78.

11. Rickert $\mathrm{CH}$, Sträter R, Kaatsch P, Wassmann H, Jürgens H, Dockhorn-Dworniczak B, Paulus W. Pediatric high-grade astrocytomas show chromosomal imbalances distinct from adult cases. Am J Pathol. 2001;158(4):1525-32.

12. Yamamoto $Y$, Mizuno R, Nishimura T, Ogawa Y, Yoshikawa $\mathrm{H}$, Fujimura $\mathrm{H}$, et al. Cloning and expression of myelin-associated oligodendrocytic basic protein. A novel basic protein constituting the central nervous system myelin. J Biol Chemistry. 1994;269(50):31725-30.

13. Joshi A, Miller Jr C, Baker SJ, Ellenson LH. Activated mutant $\mathrm{p} 110 \alpha$ causes endometrial carcinoma in the setting of biallelic Pten deletion. Am J Pathol. 2015;185(4):1104-13.

14. Kanno H, Kondo K, Ito S, Yamamoto I, Fujii S, Torigoe $\mathrm{S}$, et al. Somatic mutations of the von Hippel-Lindau tumor suppressor gene in sporadic central nervous system hemangioblastomas. Cancer Res. 1994;54(18):4845-7.14.

15. Rubin DH, Fields BN. Molecular basis of reovirus virulence. Role of the M2 gene. J Experimental Med. 1980;152(4):853-68.

16. Heglind M, Cederberg A, Aquino J, Lucas G, Ernfors P, Enerbäck S. Lack of the central nervous system-and neural crest-expressed forkhead gene Foxs1 affects motor function and body weight. Molecular Cellular Biol. 2005;25(13):5616-25.

17. Zhang X, Li Y, Xiao YY, Xing N, Liu SR, Ma XY, $\mathrm{Wu}$ B. Imaging features of Von Hippel-Lindau syndrome. Chinese J Med Imaging Tech. 2010;7:219.

Cite this article as: Vijay C, Tilak P. Determinant genes that effect the central nervous system and their antenatal identification Int J Reprod Contracept Obstet Gynecol 2020;9:4612-6. 